\title{
Trends in adult otitis media incidence - a 20-year national observational study
}

\author{
Marie Gisselsson-Solen ${ }^{1}$ \\ ${ }^{1}$ Lund Univ Hosp
}

September 25, 2021

\begin{abstract}
Objective: Otitis media (OM) is a common disease in childhood, but much less prevalent in adults, where it, however, tends to have a less benign course. The incidence of OM in children has decreased in recent years, which might be partly explained by the introduction of watchful waiting strategies, and by the introduction of conjugate pneumococcal vaccination (PCV) in children. Adult OM has been sparsely studied, and it is not known whether a herd immunity effect has been achieved after the introduction of PCV. Watchful waiting is usually not considered in adult OM patients. The purpose of this study was to use a national database to investigate the incidence of adult OM in Sweden during the last 20 years. Design: The yearly number of patients aged 20 and over, admitted to hospital with OM was obtained through a national database from 2000 to 2019. The corresponding numbers for outpatients were obtained between 2005 and 2019. Main outcome measures: incidence of acute otitis media in adults in in- and outpatient care. Results: Incidence rates decreased steadily during the study period. Comparing data on hospitalised patients from 2016-2019 to 2005-2008 (PCV was introduced in 2009), the incidence rate ratio was 0.49 (95\% CI 0.45-0.53); $\mathrm{p}<0.0001$. The corresponding figures for outpatients were 0.62 (95\% CI $0.61-0.63) ; \mathrm{p}<0.0001$. The decrease in hospital admissions was most pronounced among younger patients, whereas the opposite was true for outpatient visits. Conclusions: There has been a continuous decrease in incidence of adult patients admitted to hospital with OM in Sweden during the last twenty years. Outpatient visits for OM have declined since 2009.
\end{abstract}

\section{Hosted file}

Vuxenotiter 210705.docx available at https://authorea.com/users/436198/articles/538698trends-in-adult-otitis-media-incidence-a-20-year-national-observational-study

\section{Hosted file}

Table 1.docx available at https://authorea.com/users/436198/articles/538698-trends-in-adultotitis-media-incidence-a-20-year-national-observational-study

\section{Hosted file}

Table 2.docx available at https://authorea.com/users/436198/articles/538698-trends-in-adultotitis-media-incidence-a-20-year-national-observational-study

\section{Hosted file}

Table 3.docx available at https://authorea.com/users/436198/articles/538698-trends-in-adultotitis-media-incidence-a-20-year-national-observational-study 


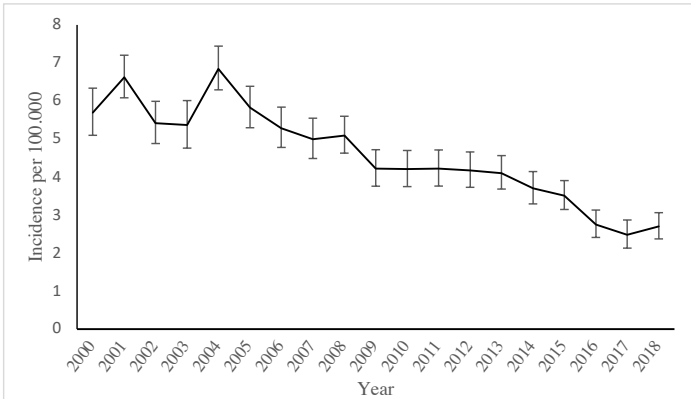

Figure 1. Yearly number of patients admitted to hospital with the diagnosis H66 


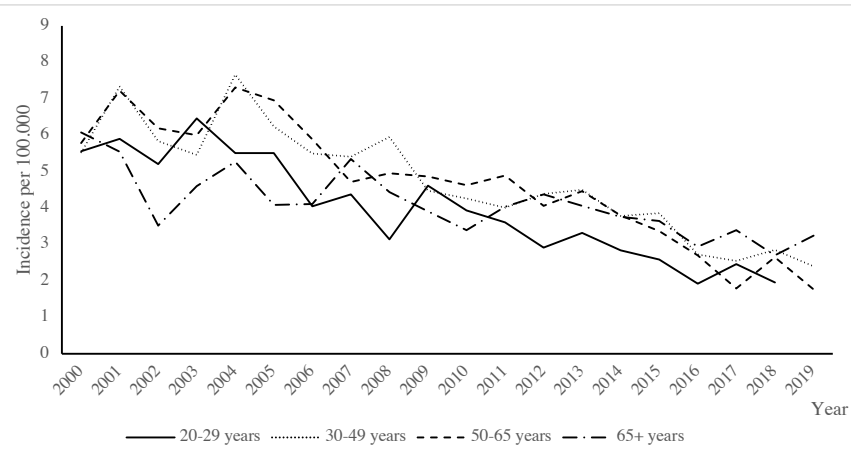

Figure 2. Incidence of patients admitted to hospital with diagnosis H66 during a 20-year period, divided by age group (Confidence intervals not shown) 


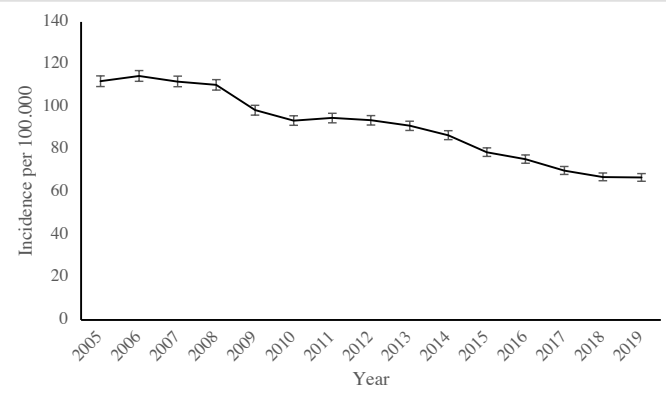

Figure 3. Incidence of outpatients with the diagnosis H.66 


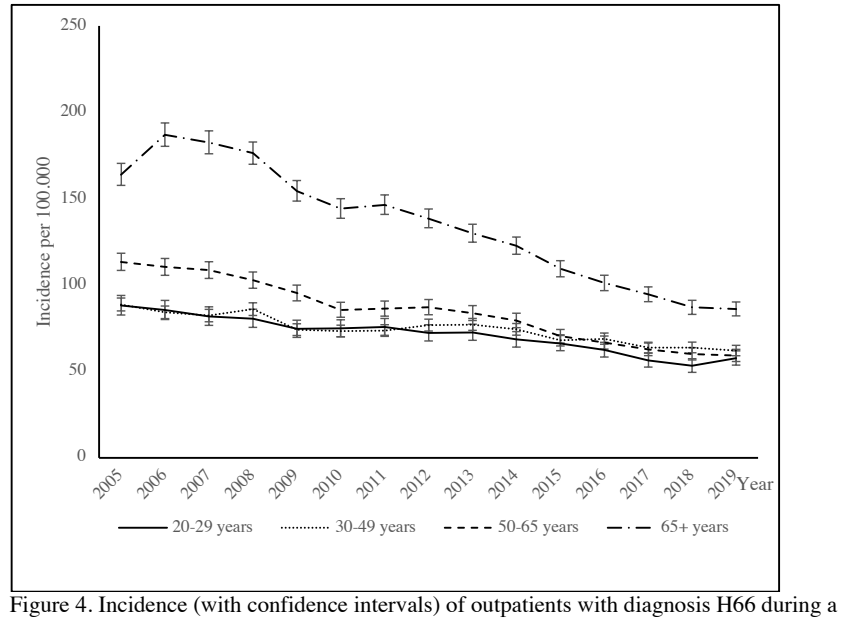

Figure 4. Incidence (with confidence intervals) of outpatients with diagnosis H66 during 15-year period, divided by age group 